\title{
Determinants of Liquidity Risk in the Commercial Banks in Bangladesh
}

\author{
Faruque Ahamed
}

\section{ABSTRACT}

The study examines the bank-specific and external factors that affect the liquidity risk in commercial banks in Bangladesh. The study has been conducted using 23 banks data from 2005-2018, and panel data is used to conduct the regression analysis. Among the bank-specific factors, asset size has a negative relationship with liquidity risk. The larger the bank size, the better the liquidity position and the lower the liquidity risk. Return on equity and capital adequacy ratio has a positive but insignificant relationship with the liquidity risks. In the case of macroeconomic factors, inflation negatively affects the liquidity risks, whereas GDP and domestic credit positively affect. Private and public sector credits increase the investments, which in turn fuel GDP growth. Growth in domestic credit reduces liquidity and may create insolvency. The loan outstanding to asset ratio is positively related to the liquidity risk of the banks. Banks usually increase the loan/advance disbursement to increase profitability, which dries out liquidity and enhances liquidity risk. The study concludes that although several factors are found insignificant yet have positive/negative relation, the banks must carefully evaluate the factors to avoid a future liquidity crisis.

Keywords: Bangladesh, Banks, liquidity risk, profitability.

Submitted : February 3, 2021

Published : February 19, 2021

ISSN: 2507-1076

DOI: $10.24018 /$ ejbmr.2021.6.1.729

Faruque Ahamed*

PhD student, Northern Illinois University, USA. (e-mail: Faruque.ahamed ${ }^{\circledR}$ niu.edu)

\section{INTRODUCTION}

Liquidity risk management is one of the core challenging tasks for financial intermediaries such as banks. As banks are primarily responsible for providing liquidity in the financial system, managing the required liquidity position, and minimizing, liquidity risk is essential for daily operations. Liquidity is the ability of a financial intermediary or bank to keep a certain balance all the time by managing the inflows and outflows efficiently [38]. Liquidity risk may generate from the mismatch between the demand and supply of funds. Banks collect funds in various deposits, credit repayments, short-term borrowing from the money market and the central bank. Customer withdrawals, credit facilities, and other expenses generate demand for funds. The gap between the supply and demands of the fund is known as net liquidity position. Banks must maintain this position carefully to avoid fund shortages and liquidity risk. [18].

Banks must carefully plan the net liquidity position as they cannot afford to have liquidity problems, which will ruin reputation and trustworthiness. Banks usually focus on asset and liabilities liquidity management to handle the liquidity position and avoid liquidity runoff. There is a trade-off between holding liquidity and profitability. Holding too much liquidity can reduce the investment opportunities and negatively affect profitability. On the other hand, fewer liquidity holdings can create liquidity risk and hurt the bank's growth in the long run. So, the risk management practice should clearly define the parameter to sufficient liquidity to insure against liquidity risk [14].

After the global financial crisis of 2007, the Basel Committee of banking supervision formulated regulations to address the systematic risks of banks, including liquidity risk, to prevent their bankruptcy. The meltdown revealed the poor liquidity management by banks, and effective policy is required to mitigate or avoid future crisis. Liquidity risk can affect banks from various directions. Aiyar [4], and Ivachina \& Shufsten [22] analyzed the effects of liquidity. They concluded that liquidity risks could severely affect the performance of the banks. The industry size, ownership structure, banking concentration, etc., can also determine the liquidity risk intensity [15].

\section{BANKING SYSTEM IN BANGLADESH}

The banking system in Bangladesh is in play for around 50 years. 60 banks, among which 48 are conducting conventional banking business, 9 are doing Islamic banking, and 3 are specialized banks, established for a specific purpose. Bangladesh Bank-The central bank of Bangladesh is responsible for formulating and implementing the financial industry's rules and regulations. In compliance with the Basel accord, Bangladesh Bank implemented the Basel III program to mitigate the liquidity shocks and strengthen the capital base against risky investments. The 
central bank published detailed guidelines to align with the regulations advised by the Basel committee in 2014. Increase the level of capital level compared to risk-weighted assets, enhanced liquidity position, raise the supervisory review process standards, and public disclosures are key issues in the guideline.

\section{LITERATURE REVIEW}

Liquidity risk is a key concern in the bank's risk management strategies. Liquidity measures a financial firm's ability to function normally and maintain a balance between financial inflows and outflows over the period [38]. There are several studies to determine the crucial factors affecting risk management.

Akhtar et al. [5] used descriptive correlations and regression analysis to investigate the relation among the liquidity risk and several bank-specific factors such as return on equity, return on assets, bank size, capital adequacy, etc. The study found that there exist positive correlations between the bank's size and liquidity risk. The return on equity and return on assets have positive but insignificant relation for conventional banks and insignificant for Islamic banks. The capital adequacy ratio is also proved to be significant for conventional banks and insignificant for Islamic banks.

Bourke [9], using international bank data for the period 1972-1981, observed that profitability is positively correlated with both capital and liquidity ratios. In another study, Rhoades [33] identified positive relation between risk and profitability for banks from 1969 to 1978 in the USA. Whereas Molyneux \& Thornton [26], using data for 19861989 in the European banking system, found that the relationship between liquidity and profitability is negative. Another study about the liquidity buffer factors over the banks of the United Kingdom and found that liquidity is very much recurring. The liquidity level compared to total assets and deposits is determined by the phase of economic growth. Higher GDP growth is observed with a lower level of liquidity in the banking system.

Vodova [39] researches the determinants of Czech banks' liquidity risk from 2006-2009. He uses the balance sheet information to identify the relationship with liquidity risk. $\mathrm{He}$ found a positive relationship between the loans to deposit ratio with the assets to deposit ratio. The study also showed the positive relationship between liquidity level and capital adequacy and the interest rate on the interbank transaction.

A study conducted by Ahmed et al. [2] over six Islamic banks in Pakistan in 2006-2009 found that asset management is positively related to liquidity risk. In contrast, the size of the bank has a negative relation with liquidity risk whereas the capital adequacy ratio is significant and positively related to the liquidity risk. The results contradict with the findings of García-Herrero and al. [16], De Jonghe [12], Pasiouras \& Kosmidou [30], Abreu \& Mendes [1], Zhang et al. [44], Bonfim et al., [8], and Demirgüç-Kunt \& Huizinga [13] which revealed that a significant level of capital reduces banks' liquidity risk.

Ismal [19] undertook a study that explains the liquidity risk management of Indonesia's Islamic banks and recommends policies to improve liquidity risk management. Proper liquidity risk analysis is essential for the ongoing operations of the banks. The author found that Islamic banks are well prepared to minimize the liquidity risk from internal and external sources. On the contrary, a study conducted over 22 conventional banks and 5 Islamic banks in Pakistan from 2005-2009 found that conventional banks are more dominant in liquidity management [28].

Waemustafa \& Sukri [41] conducted a regression analysis of Islamic banks and conventional banks from 2000 to 2010 in Malaysia. The multivariate regression analysis found that GDP and money supply is positive but not significant, but output gaps and inflation have negative significance to liquidity risk. Return on assets also depicted positive and significant relation with liquidity. However, Choon et al. [10] and Hossain \& Ahamed [17] also observed that liquidity is negatively significant to profitability.

Ramzan \& Zafar [31] examine the relations between liquidity risk and bank-specific variables of Islamic banks of Pakistan over 2007-2011. The study concludes that there is a positive and significant correlation between bank size and liquidity risk. In contrast, capital adequacy ratio, return on equity, and return on assets negatively affect liquidity risk.

Kurnia \& Muharam [24] investigate Islamic and conventional banks' liquidity in Indonesia for the period 2007-2011. They identified a positive and significant impact of return on equity on Islamic banks' liquidity risk, whereas the relation is negative and significant for conventional banks. The capital adequacy ratio is also negative and significant on liquidity risk for conventional banks.

Jedidia \& Hamza [23] studied the determinants of Islamic bank liquidity using a panel of 60 Islamic banks in the Middle East and North Africa (MENA) and Southeastern Asian countries over the period of 2004-2012. The study identified that liquidity risk depends on idiosyncratic factors such as bank profitability, capital adequacy ratio, and investment/loan ratio. Capital adequacy and investment/loan ratio have statistically significant negative relationship and return on assets have a positive relationship with the liquidity risk. The bank size has irrelevant relation, whereas gross domestic product has a negative but irrelevant association with liquidity risk.

Large banks usually have high liquidity exposure, and banks with higher capitalization have better and consistent liquidity over a long period. The study was conducted over 1080 listed and non-listed Eurozone banks with the Ordinary Least Squares (OLS) method over panel data. The banks' asset quality has short-term liquidity risk, and in the event of a crisis, the liquidity risk management is affected only for a short period [11].

Sopan \& Dutta [35] explores the determinants of liquidity risk in 45 Indian banks over 2005 to 2016 financial year period by examining the bank-specific and macroeconomic factors that affect a bank's liquidity. The bank-specific factors include the bank size, profitability, capitalization, etc. Macroeconomic determinant includes GDP and inflation rate. The empirical analysis found that bank size, profitability ratios, and inflation rate positively affect the liquidity risk, whereas GDP has negative effects.

Mugenyah [27] conducted a study over commercial banks licensed in Kenya between 2010 and 2014. He used multiple 
regression to determine the effects of capital adequacy ratio, liquid assets ratio, ownership type, size, and leverage to identify the impact over liquidity risk. The study concluded that capital adequacy had a positive effect while liquid asset ratio, ownership type, size, and leverage negatively affected liquidity risk.

Sukmana \& Suryaningtyas [37] investigated the relationship between the liquidity risks and bank-specific factors. The study found the significant and positive relation of ROA with the liquidity risk, whereas capital adequacy ratio is negative and significant relationship with the liquidity risk in Indonesian Conventional Banks. In Islamic banks, the capital adequacy ratio has a significantly positive effect on liquidity risk, while return on asset shows a negative and significant result.

In another study, Zaghdoudi \& Hakimi [43], covering ten Tunisian banks representing all Tunisian banking sectors, observed from 1980 to 2015 . The analysis found that the liquidity risk of Tunisian banks depends on the bank's internal factors such as loans and advances, bank size, etc. Among the macroeconomic factors, economic growth has a positive and significant effect, whereas inflation impacts negatively but not significantly the liquidity risk of Tunisian banks.

A study over old European Union countries and so-called New European Union countries was conducted to measure the liquidity risk of bank-specific and macroeconomic factors. The old European Union countries include Austria, Belgium, Germany, Denmark, Spain, Finland, France, the UK, Greece, Ireland, Italy, and Portugal. The new European Union countries include Bulgaria, the Czech Republic, Hungary, Poland, Romania, Slovenia, and Slovakia. The study found internal determinants that affect the level of liquidity risk, regardless of the form of liquidity risk measure adopted and the country in which they operate. Macroeconomic factors such as GDP growth negatively correlate with liquidity in both new and old European Union countries. The increase of inflation level affects the increase of liquidity level. [40]

Iqbal [21] investigated liquidity risk against the nonperforming loan ratio, return on assets, return on equity, bank size, and capital adequacy ratio of Pakistan's conventional and Islamic banks for the period 2007-2010. The study found significant and positive relation of capital adequacy ratio, return on assets, return on equity, and bank size with liquidity risks.

Anam et al. [7] studied the significance of a firm's size, net working capital, return on equity, capital adequacy and return on assets on liquidity risk management of Bangladeshi banks for 2006-2010. The investigation reveals that net working capital, capital adequacy ratio, and return on assets positively influence the liquidity risk.

\section{RESEARCH METHODOLOGY}

\section{A. Data \& Variables}

This study's data consists of 23 banks consisting of 17 conventional banks and six full-fledged Islamic banks in Bangladesh. These banks cover significant assets and market share in the banking industry. The annual report of these banks is used to collect the related data from 20052018. Liquidity risk is measured by the advances to deposit ratio (ADR), the maximum cap a bank can lend money to borrowers compared to deposits collected. The higher this ratio means less liquid money is available to banks. In Bangladesh, the advances to deposits ratio is $85 \%$ and $90 \%$ for the conventional and Islamic banks, respectively. Due to the Covid-19 effect, the ADR rate increased to $87 \%$ and $92 \%$ for the conventional and Islamic banks, respectively [3]. The independent variables both bank-specific and macroeconomic factors. In the bank-specific variables, asset size, return on assets, return on equity, net profit margin, and loans/advances to the asset have been used. GDP growth rate, inflation rate, and domestic credit in terms of GDP have been used as macroeconomic variables.

\section{B. Empirical Model \& Tests}

In this study, the panel data estimations allow to control for observable and unobservable bank level and time level heterogeneity. The specification of the empirical model is:

$$
\begin{aligned}
\mathrm{LR}_{\mathrm{ij}}=\beta_{0}+\beta_{1} \mathrm{Size}_{\mathrm{ij}} & +\beta_{2} \mathrm{ROE}_{\mathrm{ij}}+\beta_{3} \mathrm{CAR}_{\mathrm{ij}}+\beta_{4} \mathrm{INF}_{\mathrm{j}}+\beta_{5} \mathrm{GDP}_{\mathrm{j}} \\
& +\beta_{6} \mathrm{DC}_{\mathrm{j}}+\beta_{7} \mathrm{LA}_{\mathrm{ij}}+\mathrm{e}_{\mathrm{ij}}
\end{aligned}
$$

where LR implies the liquidity ratio for the ith bank in jth time, the SIZE indicates logarithm of the asset size of the banks, ROE implies return on equity, CAR indicates the capital adequacy ratio, INF is the inflation rate is the 12 month average ratio of the year, GDP implies gross domestic product growth, DC indicates domestic credit as a

\begin{tabular}{|c|c|c|c|}
\hline Symbol & Variable & Proxies & $\begin{array}{l}\text { Hypothesis } \\
\text { relationship }\end{array}$ \\
\hline LR & Liquidity risk & $\begin{array}{l}\text { Loans/advances to } \\
\text { Deposit ratio }\end{array}$ & N/A \\
\hline AS & Bank size & $\begin{array}{l}\text { Logarithm of } \\
\text { Bank Size }\end{array}$ & Negative \\
\hline $\mathrm{ROE}$ & Return on Equity & $\begin{array}{l}\text { Net profit after tax } \\
\text { to equity ratio }\end{array}$ & Positive \\
\hline CAR & $\begin{array}{c}\text { Capital } \\
\text { Adequacy ratio }\end{array}$ & $\begin{array}{c}\text { (Tier } 1 \text { capital + } \\
\text { Tier } 2 \\
\text { capital)/Risk } \\
\text { weighted assets }\end{array}$ & Positive \\
\hline LA & Loan/advances & $\begin{array}{c}\text { Loans/advances to } \\
\text { assets ratio }\end{array}$ & Positive/negative \\
\hline INF & Inflation rate & - & Negative \\
\hline GDP & GDP growth & $\begin{array}{l}\text { Real GDP growth } \\
\text { rate }\end{array}$ & Positive/negative \\
\hline DC & Domestic Credit & $\begin{array}{c}\text { Domestic } \\
\text { Credit/GDP }\end{array}$ & Positive \\
\hline
\end{tabular}
percentage of GDP and LA means loans/advances to assets.

For analyzing panel data, researchers can use few methods such as Pooled Ordinary Least Square (POLS), the fixed-effect model, the random effect model, etc. When the number of independent variables is fixed, and all the variables are represented in ratios, the fixed-effect model fits the best in regression analysis and variance analysis [6]. In this study, the number of independent variables is fixed. Still, not all the terms are expressed as ratios Hausman test is conducted to confirm the Random Effect Model is more appropriate in this dataset. Besides this for robustness check, Pooled Ordinary Least Square (POLS) has also been used in the study. 


\section{Estimation Results}

The statistic follows distribution statistics Chi-Squares with degrees of freedom (df) of free variables [37]. The random effect is in the null hypothesis, and the fixed effect is in the alternative hypothesis. The equation of the Haussmann test is as follows:

$$
\operatorname{chi} 2(7)=(b-B)^{\prime}\left[\left(V_{-} b-V \_B\right)^{(-1)}\right](b-B)
$$

The Haussmann test results indicate that the random effect is better than the fixed effect for this panel data set. The p-value is 0.07839 , which is greater than the significance level of 0.05 , indicating that the null hypothesis is accepted.

The output from both the random effect model and pooled ordinary least square method depicts consistency, proving the robustness of the dataset. The R-squared and adjusted Rsquared for the random effect method is $74.58 \%$ and $74.01 \%$, respectively. In the POLS model, the R-squared and adjusted R-squared are $73.86 \%$ and $71.16 \%$. Both the model explained most of the variation of bank specific \& macroeconomic variables.

TABLE 2: RANDOM EFFECT MODEL

\begin{tabular}{ccccc}
\hline \multicolumn{5}{c}{ TABLE 2 RANDOM EFFECT MODEL } \\
\hline AS & Estimate & Std. Error & t-value & Probability \\
ROE & -0.0700552 & 0.0401005 & -1.7470 & 0.080639 \\
CAR & 0.0076724 & 0.089141 & 0.0861 & 0.931411 \\
INF & -1.03749317 & .3373940 & 2.5932 & 0.009509 \\
GDP & 3.9294020 & .8542421 & -1.2143 & .0224628 \\
DC & 0.4344033 & .5579858 & 1.9159 & 0.055378 \\
LA & 1.1514946 & 0.0394421 & 29.1946 & 0.436262 \\
\hline
\end{tabular}

\begin{tabular}{ccccc}
\multicolumn{5}{c}{ TABLE 3: POOLED ORDINARY LEAST SQUARE } \\
\hline Variable & Estimate & Std. Error & t-value & Probability \\
\hline AS & -0.114521 & 0.073379 & -1.5607 & 0.11969 \\
ROE & 0.024076 & 0.095577 & 0.2519 & 0.80129 \\
CAR & 0.637597 & .488954 & 1.3040 & 0.19326 \\
INF & -1.143529 & .885826 & -1.2909 & 0.19776 \\
GDP & 3.882306 & 2.133535 & 1.8197 & 0.06984 \\
DC & 1.048544 & .961116 & 1.0910 & 0.27619 \\
LA & 1.148986 & .041960 & 27.3828 & $2 \mathrm{e}-16$ \\
\hline
\end{tabular}

\begin{tabular}{ccccccccc}
\multicolumn{10}{c}{ TABLE 4: CORRELATION MATRIX } \\
\hline & LR & AS & ROE & CAR & INF & GDP & DC & LA \\
\hline LR & 1. & -.15 & -.04 & -.08 & -.02 & .06 & -.09 & .86 \\
AS & .15 & -1.0 & -.21 & .19 & -.23 & .35 & .91 & -.14 \\
ROE & -.04 & -.21 & 1.0 & .04 & .03 & -.18 & -.20 & -.06 \\
CAR & -.08 & .189 & .04 & 1.0 & .07 & -.17 & .24 & -.16 \\
INF & -.02 & -.23 & .03 & .07 & 1.0 & -.06 & -.14 & -.01 \\
GDP & .060 & .352 & -.18 & -.17 & .06 & 1.0 & .42 & .04 \\
DC & -.09 & .911 & -.20 & .24 & -.14 & .42 & 1.0 & -.10 \\
LA & .858 & -.14 & -.06 & -.16 & -.01 & .036 & -.10 & 1.0 \\
\hline
\end{tabular}

The random-effects model finds that the banks' asset size has a negative relation with liquidity risk. The larger the bank size, the higher the liquidity position, so the liquidity risks are lower. The POLS results also confirm the findings. Although in both cases, asset size proves to be insignificant. There is a positive relationship between bank size and liquidity position of the banks, which is like the findings of Isshaq \& Bokpin [20] and Lucchetta [25]. By contrast, studies by Rauch et al. [32] find that bank size has no significant effect on liquidity.

Return on equity (ROE) explains the return against the equity value and expresses management efficiency in generating value for the shareholders. In both random effects and the POLS method, ROE seems to have positive but insignificant relation with liquidity risk. The results are like Akhtar et al. [5] and Iqbal [21]. In contrast, Kurnia \& Muharam [24] identified a positive and significant impact of ROE on Islamic banks' liquidity risk, whereas the relation is negative and significant for conventional banks. The more liquid a bank is, the lower its return on equity considering ceteris paribus condition.

The capital adequacy ratio is measured by guidelines provided by the Basel committee of banking supervision. Generally, tier 1 and tier 2 capital are added and divided by the risk-weighted assets to compute the ratio. The ratio demonstrates the extent of financing of risky assets by bank's own capital. A higher ratio means the bank has enough support for the potential losses from risky investments. [29]. The results in both tests show that CAR has a positive but insignificant influence on liquidity risks. The findings are very much similar to Akhtar et al. [5], Iqbal [21], Sukmana \& Suryaningtyas [37], and Anam [7].

Inflation reduces the purchasing power and makes products and services pricy. Both the tests conclude that inflation has a negative relation with liquidity risks. However, the random-effects model shows significance, but POLS exhibits insignificant relation. The results are similar with the findings of Vodova [39] and Cucinelli [11] but contradicts with the findings of Sopan \& Dutta [35], Sudirman [36] and Singh \& Sharma [34].

GDP is the most used proxy for macroeconomic indicators to identify how the exogenous factors affect the banking liquidity risks. Economic growth attracts long term investments and reduces the holdings of liquid assets. The growth of the GDP is therefore expected to have a positive relationship with liquidity risks. Both the model finds that GDP growth rate has a strong connection with liquidity risks. However, both tests certify that the GDP growth rate is insignificant at a 5\% significance level. Sopan \& Dutta [35], Waemustafa \& Sukri [41], and Jedidia \& Hamza [23] also have similar findings, whereas Wójcik-Mazur \& Szajt. [40] concludes the negative relationship between GDP and liquidity risk.

Financial resources provided by the financial institutions to households and businesses in various forms sums up the domestic credit. The total domestic credit as a percentage of GDP expresses loans/advances in the economy primarily by banks. Higher domestic credit drains liquidity from the financial system and enhances liquidity risks. This macroeconomic variable investigates the exogenous effect on liquidity risk. Both tests conclude that domestic credit to GDP has strong positive but insignificant relation with liquidity risk.

The loans/advances measure the total outstanding loans compared to the total assets. If the ratio is high, it means the bank's provided more credit, the liquidity position is low, and it is more exposed to liquidity risks. The random effects and POLS model estimates the positive but significant effect of credit outstanding on liquidity risks. Zaghdoudi \& Hakimi [42] and Bonfim \& Kim [8] also concludes that banks specialized in higher loan grating is subject to liquidity risks. 


\section{CONCLUSION}

The study investigates the determinants of banks' liquidity risks using panel data of 23 banks for 14 years. The dataset was adjusted to correct the biases caused by endogenous explanatory variables. Based on the estimation results, bank size and inflation negatively affect the liquidity risks. The return on assets, capital adequacy ratio, GDP growth, and domestic credits as a percentage of GDP and loan to asset ratio positively impact. Large banks are exposed to low liquidity risk due to their sheer capital size and transaction volume. The banking sector asset is largely composed of loans, and in the previous years, the loan growth is higher than the deposit growth. Failure to manage the duration between assets and liabilities can lead to liquidity dry out and insolvency. Highly capitalized banks exhibit strong liquidity in the long run, whereas better asset quality can provide liquidity relaxation in the short run. The Basel committee introduced two new indicators, liquidity coverage ratio (LCR) and net stable funding ratio (NSFR), to measure the liquidity position. In the near future, the intends to investigate the bank specific and external factors affecting the above liquidity ratios in compliance with the Basel Committee requirements.

\section{REFERENCES}

[1] Abreu M. and V. Mendes. 2002. "Commercial bank interest margins and profitability: evidence from E.U countries", Porto Working paper series.

[2] Ahmed, N., Ahmed, Z., \& Naqvi, I. (2011). Liquidity Risk and Islamic Banks: Evidence from Pakistan. Interdisciplinary Journal of Research in Business, 1(9), 99-102

[3] Ahamed, F. (2021). Macroeconomic Impact of Covid-19: A case study on Bangladesh. IOSR Journal of Economics and Finance (IOSR-JEF), 12(1), 2021, pp. 24-29.

[4] Aiyar, S. (2012). From financial crisis to great recession: The role of globalized banks. American Economic Review, 102(3), 225-30.

[5] Akhtar, M. F., Ali, K., \& Sadaqat, S. (2011). Liquidity risk management: a comparative study between conventional and Islamic banks of Pakistan. Interdisciplinary journal of research in business, 1(1), 35-44.

[6] Alison, P.D. (2005), "Fixed Effects Regression Methods for Longitudinal Data: Using SAS," SAS Institute.

[7] Anam, S. et.al. (2012). Liquidity Risk Management: A Comparative Study Between Conventional and Islamic Banks of Bangladesh. Research Journal Economics, Business, ICT. Vol. 5: 1-5

[8] Bonfim, D., Barros, P. P., Kim, M., \& Martins, N. C. (2011). Estimating the impact of bank mergers: an application to the Portuguese banking system. Economic Bulletin and Financial Stability Report Articles and Banco de Portugal Economic Studies.

[9] Bourke, P. (1989). Concentration and other determinants of bank profitability in Europe, North America and Australia. Journal of Banking \& Finance, 13(1), 65-79.

[10] Choon, L. K., Hooi, L. Y., Murthi, L., Yi, T. S., \&Shven, T. Y. (2013). The determinants influencing liquidity of Malaysia commercial banks, and its implication for relevant bodies: evidence from 15 malaysian commercial banks (Honours Unpublished Thesis).UniversitiTunku Abdul Rahman, Kampar.

[11] Cucinelli, D. (2013). The determinants of bank liquidity risk within the context of euro area. Interdisciplinary Journal of Research in Business, 2(10), 51-64.

[12] De Jonghe, O. (2010). Back to the basics in banking? A microanalysis of banking system stability. Journal of financial intermediation, 19(3), 387-417.

[13] Demirgüç-Kunt, A., \& Huizinga, H. (1999). Determinants of commercial bank interest margins and profitability: some international evidence. The World Bank Economic Review, 13(2), 379-408.

[14] Diamond, D. W., \& Dybvig, P. H. (1983). Bank runs, deposit insurance, and liquidity. Journal of political economy, 91(3), 401-419.
[15] Dinç, I. S. (2005). Politicians and banks: Political influences on government-owned banks in emerging markets. Journal of financial economics, 77(2), 453-479.

[16] García-Herrero, A., Gavilá, S., \& Santabárbara, D. (2009). What explains the low profitability of Chinese banks?. Journal of Banking \& Finance, 33(11), 2080-2092.

[17] Hossain, M. S., \& Ahamed, F. (2015). Determinants of bank profitability: A study on the banking sector of Bangladesh. Journal of Finance and Banking, 13(1), 43-57.

[18] Hudgins, C., Rose, S., Fifield, P. Y., \& Arnault, S. (2013). Navigating the legal and ethical foundations of informed consent and confidentiality in integrated primary care. Families, Systems, \& Health, 31(1), 9.

[19] Ismal, R. (2010). Assessment of liquidity management in Islamic banking industry. International Journal of Islamic and Middle Eastern Finance and Management.

[20] Isshaq, Z., \& Bokpin, G. A. (2009). Corporate liquidity management of listed firms in Ghana. Asia-Pacific Journal of Business Administration.

[21] Iqbal, A. (2012). Liquidity risk management: a comparative study between conventional and Islamic banks of Pakistan. Global journal of management and business research, 12(5).

[22] Ivashina, V., and Scharfstein, D, Bank lending during the financial crisis of 2008, Journal of Financial Economics, 97, (2010), 319- 338.

[23] Jedidia, K. B., \& Hamza, H. (2015). Determinants of liquidity risk in Islamic banks: A panel study. Islamic Management and Business, 2(2), 137-146

[24] Kurnia, H. P., \& Muharam, H. (2012). The Influence of Fundamental Factors to Liquidity Risk on Banking Industry (Case Study between Conventional and Islamic Banks in Indonesia) (Doctoral dissertation, Fakultas Ekonomika dan Bisnis).

[25] Lucchetta, M. (2007). What do data say about monetary policy, bank liquidity and bank risk taking?. Economic notes, 36(2), 189-203.

[26] Molyneux, P., \& Thornton, J. (1992). Determinants of European bank profitability: A note. Journal of banking \& Finance, 16(6), 1173-1178.

[27] Mugenyah, L. O. (2015). Determinants of liquidity risk of commercial banks in Kenya (Doctoral dissertation, University of Nairobi).

[28] Muhammad, H., Tariq, M., Tahir, A., \& Momeneen, W. (2009) Comparative Performance study of conventional and Islamic Banking in Pakistan. FAST School of Business National University of Computer \& Emerging Sciences.

[29] Ojo, M. (2010). "Risk management by the Basel Committee: Evaluating progress made from the 1988 Basel Accord to recent developments". Journal of Financial Regulation and Compliance, 18, 305-315.

[30] Pasiouras, F., \& Kosmidou, K. (2007). Factors influencing the profitability of domestic and foreign commercial banks in the European Union. Research in International Business and Finance, 21(2), 222-237.

[31] Ramzan, M., \& Zafar, M. I. (2014), Liquidity Risk Management in Islamic Banks: A Study of Islamic Banks of Pakistan,

[32] Rauch C., Steffen, S., Hackethal, A. and M. Tyrell, 2011, Determinants of Bank Liquidity Creation, Working Paper. Interdisciplinary Journal of Contemporary Research in Business, 5 (12), 199-215.

[33] Rhoades, S. A. (1985). Market share as a source of market power: Implications and some evidence. Journal of Economics and Business, 37(4), 343-363.

[34] Singh, A., \& Sharma, A. K. (2016). An empirical analysis of macroeconomic and bank-specific factors affecting liquidity of Indian banks. Future Business Journal, 2(1), 40-53.

[35] Sopan, J., \& Dutta, A. (2018). Determinants of liquidity risk in Indian banks: A panel data analysis. Asian Journal of Research in Banking and Finance, 8(6), 47-59.

[36] Sudirman, I. (2015, March). Determinants of bank liquidity in Indonesia: Dynamic panel data analysis. 11th International Annual Symposium on Management, The Singhasari Resort, Batu, Malang, Indonesia. DOI10.2139/ssrn.2583985

[37] Sukmana, R., \& Suryaningtyas, S. (2016). Determinants of liquidity risk in Indonesian Islamic and conventional banks. [1] Al-Iqtishad: Jurnal Ilmu Ekonomi Syariah, 8(2), 187-200.

[38] Vento, Gianfranco A., and Pasquale La Ganga. "Bank liquidity risk management and supervision: which lessons from recent market turmoil." Journal of Money, Investment and Banking 10.10 (2009): 78-125.

[39] Vodova, P. (2012). Determinants of commercial banks' liquidity in Poland. ratio, 50(2).

[40] Wójcik-Mazur, A., \& Szajt, M. (2015). Determinants of liquidity risk in commercial banks in the European Union. Argumenta Oeconomica, 2(35), 25-48. 
[41] Waemustafa, W., \& Sukri, S. (2016). Systematic and unsystematic risk determinants of liquidity risk between Islamic and conventional banks. International Journal of Economics and Financial Issues, 6(4), 1321-1327.

[42] Waemustafa, W., \& Sukri, S. (2016). Systematic and unsystematic risk determinants of liquidity risk between Islamic and conventional banks. International Journal of Economics and Financial Issues, 6(4), 1321-1327.

[42] Zaghdoudi, K., \& Hakimi, A. (2017). The determinants of liquidity risk: Evidence from Tunisian banks. Journal of Applied Finance and Banking, 7(2), 71.

[43] Zaghdoudi, K., \& Hakimi, A. (2017). The determinants of liquidity risk: Evidence from Tunisian banks. Journal of Applied Finance and Banking, 7(2), 71.

[44] Zhang, Q., Çağın, T., Van Duin, A., Goddard III, W. A., Qi, Y., \& Hector Jr, L. G. (2004). Adhesion and nonwetting-wetting transition in the Al/ $\alpha-\mathrm{Al} 2 \mathrm{O} 3$ interface. Physical Review B, 69(4), 045423.

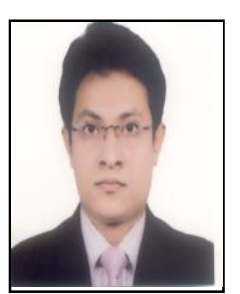

Faruque Ahamed is a Ph.D. student in economics at Northern Illinois University. He completed his graduation from the University of Dhaka, majoring in Finance. He worked in the Bangladesh Bank-The central bank of Bangladesh for almost 5 years. He was a contributor to the Financial Stability Report and Quarterly Financial Stability Assessment Report. The reports mainly focus on the country's Macroeconomic development, banking system analysis, and foreign exchange market situation. The author has a research interest in macroeconomic policies and has several publications on the subject. 